Jpn. J. Oral Biol., 24 : 385-392, 1982.

\title{
形成期の膜性骨の走査電顕的超微形態
}

\author{
新村明達山合友一朗滝口励司 \\ 昭和大学歯学部第一口腔解剖学教室*（主任 : 滝口励司教授）
}

〔受付 : 昭和 57 年 3 月 20 日]

\section{Scanning electron microscopy of forming membrane bone}

\author{
Akisato Niimura, Tomoichiro Yamaai and Reiji Takiguchi \\ The First Department of Oral Anatomy, School of Dentistry, Showa University, \\ 1-5, Hatanodai, Shinagawa-ku, Tokyo, 142 \\ (Chief : Prof. Reiii Takiguchi)
}

[Accepted for publication : March 20, 1982]

Key words: intramembraneous ossification/membrane bone/forming surface/resorbing surface/collagen fibril

\begin{abstract}
For the purpose of observing the ultrastructure of the membrane bone during embryonal development, scanning electron microscopic investigation of the ultrastructures of the internal and external surfaces of the parietal bone in the fetus was carried out in the latter part of the embryonic period, with the following results:

Trabeculae had formed on the internal and external surfaces of the fetal parietal bone. Numerous cavities of blood vessels were opened among the trabeculae showing the vascular walls. On the external surface of the parietal bone a matrix of compact collagen fibrils running parallel in roughly uniform direction had been formed. The outermost layer, however, was composed of irregularly oriented reticular collagen fibrils. The internal surface of the parietal bone was under resorption. The resorbing surface consisted of numerous large and small resorption lacunae of varying shapes, the collagen fibrils exposed at the bottom of these lacunae showed different orientations, and osteocyte lacunae were observable in the lacunae exposed by the resorption.

Along the vascular walls of the blood vessels opened on the internal and external surfaces of the parietal bone a matrix had already been formed. Whereas the matrix was composed of compact collagen fibrils running parallel in almost uniform direction, its outermost layer was made up of irregularly oriented reticular collagen fibrils.
\end{abstract}

\section{緒言}

胎生期における骨の発生様式は, 膜内骨化（intramembraneous ossification) と軟骨内骨化 (endochondral ossification）とに区別される。大部 分の骨は将来, 骨が形成される部分に, いったん 軟骨性の原基が形成され，ついで骨組織に置換さ

* 東京都品川区旗の台 1-5-8（产 142）
れる, いわゆる軟骨内骨化の様式によって形成さ れる。一方, 膜内骨化によって形成される骨は, 頭頂骨などの頭蓋冠の骨と鎖骨とである。膜内骨 化は骨芽細胞によって，皮膚の結合組織層に骨組 織が形成されることをいい，この発生様式によっ て形成された骨を膜性骨（membrane bone）と称 している。

著者らはこれまでに走査電子顕微鏡によって, 
成長期の下顎頭を用いて, 軟骨基質の石灰化過程 について検索してきた ${ }^{1-4)}$ 。さらに，軟骨内骨化 についても成長期の下顎頭によって検索した ${ }^{5)}$ 。 ついで，骨基質形成面 ${ }^{6,7)}$ と骨小腔壁の 基質形成 面 ${ }^{8-11)}$ との超微形態についても走査電子顕微鏡に よって検索してきた。しかしながら，膜内骨化に よって形成される膜性骨の超微形態についてはい まだ報告を見ない。

典型的な膜性骨である頭蓋冠の骨は，最初に骨 化点が形成され，骨化点からは海綿状の骨質が周 囲に放射状に形成されていく。ついで骨の中心部 からしだいに緻密な骨質へと変化していく。頭蓋 冠をつくっている膜性骨は，一応の形態が形成さ れたのちにも，脳の成長に伴って外方へ形成され つづけるので，頭頂骨などの頭蓋冠の骨は，骨の 彎曲度が変化する。すなわち，骨の外面には基質 が形成され，逆に内面は吸収されるといわれてい る。そこで膜性骨の表面の動向を検索する目的で, 胎生期後半の胎児の頭頂骨を用いて，骨の外面お よび内面の超微形態を走査電子顕微鏡で検索し, 若干の新知見を得たので，ここにその結果を報告 する。

\section{試料および方法}

研究試料としては，胎生 6 か月の 3 体の胎児の 頭頂骨を使用した。胎児に臍動脈から $2.5 \%$ グルタ ールアルデヒド溶液（リン酸緩衝液， $\mathrm{pH} 7.4$ ) の 灌流固定を行い，胎児からすみやかに頭頂骨を摘 出し, 頭頂骨の各部分を $5 \mathrm{~mm}$ 前後の大きさの試 料とした。各試料は $2.5 \%$ グルタールアルデヒド溶 液(リン酸緩衝液, $\mathrm{pH} 7.4$ ) によって, $4^{\circ} \mathrm{C}$ で 3 時 間固定した。水洗後, 試料の表面の骨膜の線維層 を，実体顕微鏡下でピンセットによって剝離した。 ついで，試料を $1 \%$ \%リプシン溶液（リン酸緩衝 液, $\mathrm{pH} 7.4)$ 中に, 48 時間, $37^{\circ} \mathrm{C}$ の恒温器中に 放置し, 骨基質の表面の細胞を消化させ, 形成面 または吸収面を露出させた。水洗後, 試料はアル コール上昇系列によって脱水し, 酢酸イソアミー ルで置換して, 液体炭酸ガスで臨界点乾燥を施し た。乾燥後, 観察面に白金のイオンスパッタコー ティングを施し，走査電子顕微鏡によって観察し た。

\section{結果}

膜性骨である胎児の頭頂骨の結節部には，内外 面ともにきわめて多数の不正円形の血管孔が開口 している (Fig. 1)。結節の周囲の部分には骨梁が 形成されて㧍り，骨梁間には多数の血管腔壁が開 ロしている (Fig. 2)。頭頂骨の周縁部には疎な骨 梁が形成されており，骨梁はいまだ骨化していな い結合組織上に延びている (Fig. 3)。頭頂骨の外 表面には基質が形成されており(Fig. 4-9)，内表 面は吸収されている（Fig. 10，11）が，血管腔壁 には基質形成が認められる(Fig. 12-14)。

頭頂骨の外表面は一定方向に平行に走向してい る密な膠原原線維で形成されている。外表面には 不完全に形成されている骨小腔が認められる。外 表面の最表層は不規則な走向の膠原原線維によっ て, 膠原原線維網が形成されている (Fig. 4)。骨 基質の最表層は密な膠原原線維網によって形成さ れている部分（Fig. 5) と，柾な膠原原線維網に よって形成されて扔り，下層の一定方向に走向し ている密な膠原原線維が明膫に認められる部分 (Fig. 6) とがある。

頭頂骨の外表面では，骨基質の表面は一定方向 に平行に走向している密な膠原原線維で形成され ており，骨基質の最表層は密な膠原原線維網で形 成されているが，弱扡大像では Fig. 4 の最表層 に形成されている膠原原線維網のように明膫でな 、部分がある (Fig. 7)。骨基質の最表層を形成し ている膠原原線維網の大部分が，下層の密な膠原 原線維上に癒合している部分（Fig. 8) と，下層 の密な膠原原線維上に完全に癒合している部分 (Fig. 9）とが認められる。骨基質の表面にはきわ めて多数の骨細管が開口しており，穊状を呈して いる部分も認められる (Fig. 9)。

頭頂骨の内表面は吸収が進行しており，吸収面 は大小様々の多数の不定形の吸収窩からなってい る。各吸収窩は深さが異なっており，それぞれの 吸収窝底の膠原原線維の走向が異なっている。吸 収窝底には吸収によって露出された多数の骨小腔 が認められる(Fig. 10)。吸収窩底には吸収によ って露出された膠原原線維が認められる。吸収窩 底の膠原原線維の走向は同一の吸収窩でも部分的 


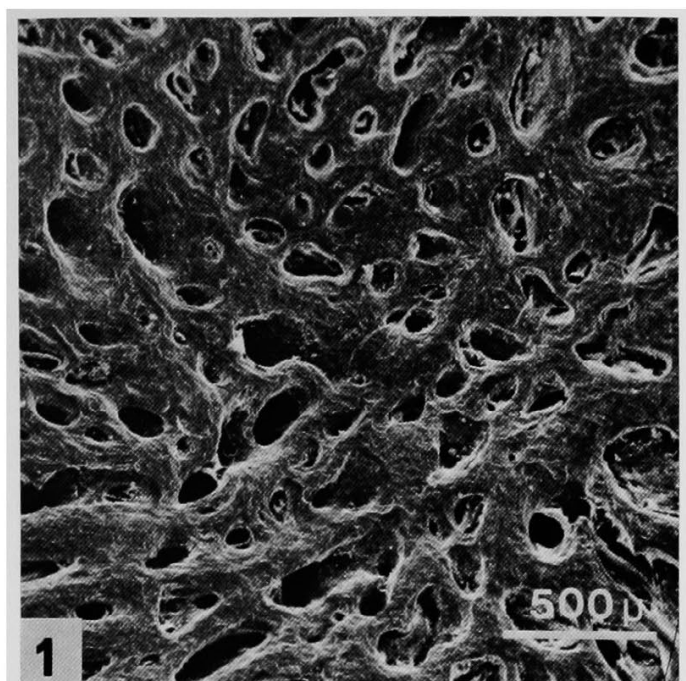

Fig. 1 Tubercle region of the internal surface of the fetal parietal bone showing numerous openings of blood vessel holes

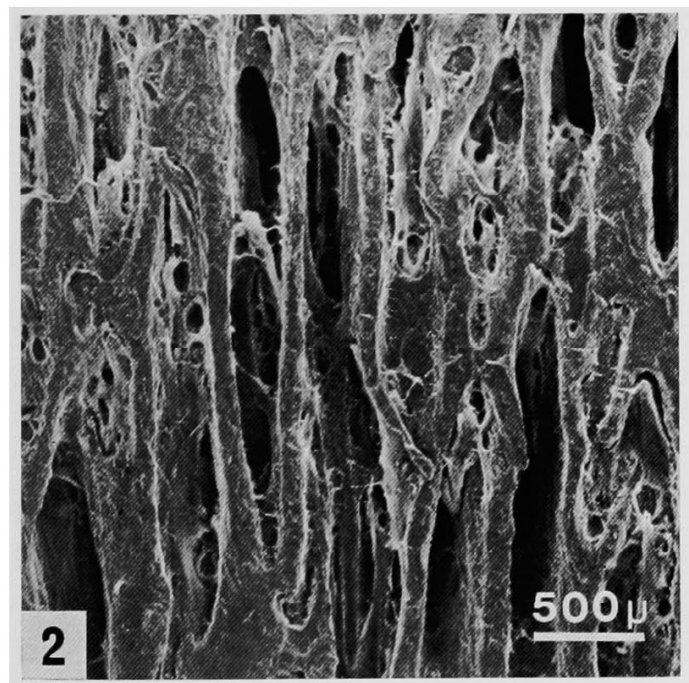

Fig. 2 Circumference of the external tubercle of the parietal bone showing inner walls of blood vessels exposed between trabeculae

に異なっているが，大部分は網状構造を呈してい る。吸収窩底に露出されている骨小腔壁は，きわ めて密な一定方向に走向している膠原原線維で形 成されているが，壁の最表層を形成している膠原 原線維の走向は不規則であり網状構造を呈してい る。骨小腔壁には 同大の骨細管が開口している

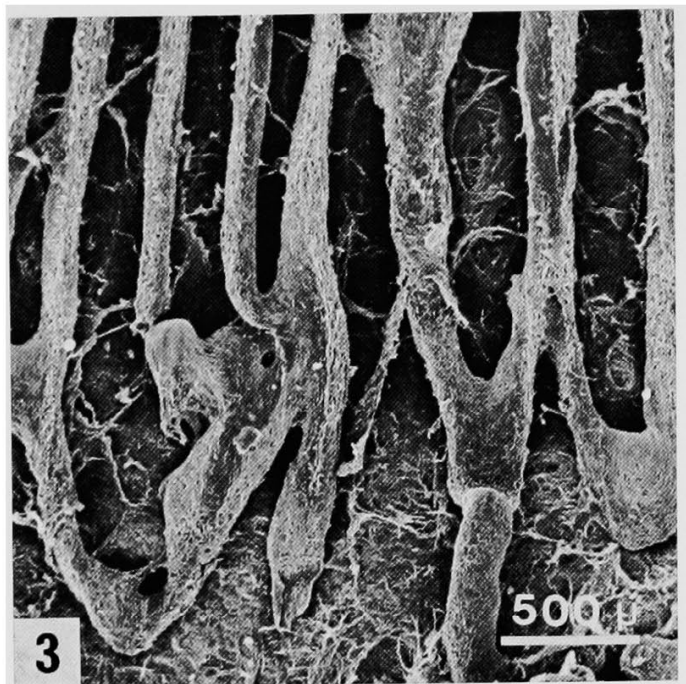

Fig. 3 Marginal region of the internal surface of the parietal bone showing sparse formation of trabeculae

(Fig. 11)。

頭頂骨の内外面に開口している血管腔壁は，頭 頂骨外面と同様な超微形態を呈している。血管腔 壁は一定方向にほぼ平行に走向している密な膠原 原線維で形成されているが，最表層は不規則な走 向の膠原原線維によって, 網状構造が 形成され ている(Fig，12）。血管腔壁の最表層は密な膠原 原線維網によって形成されており，下層を一定 方向に走向している膠原原線維が 不明瞭な 部分 (Fig. 13) と，疎な膠原原線維網によって形成さ れている部分（Fig. 14）とが認められる。

\section{考察}

骨は胎生期において軟骨内骨化か膜内骨化によ って形成される。軟骨内骨化では軟骨性の原基が 形成され，さらに軟骨基質が石灰化し，ついで， 石灰化軟骨基質が吸収され，索状になった石灰化 軟骨基質の表層に骨基質が付加される。胎生期に 形成される大部分の骨は軟骨内骨化の様式によっ て発生する。骨の軟骨性原基を構成している硝子 軟骨の石灰化過程 ${ }^{1-4)}$ と, 軟骨内骨化 ${ }^{5)}$ とは，これ までに走查電子顕微鏡によって詳細に検索してき た。しかしながら，膜内骨化による膜性骨の形成 過程については，これまでに報告を見ない。典型 的な膜生骨である頭蓋冠を形づくっている骨は， 


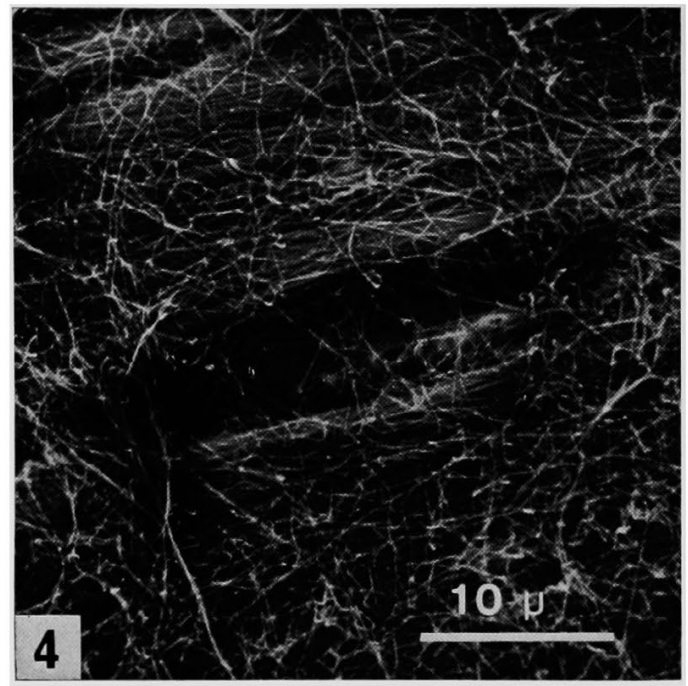

Fig. 4 Outermost layer of the external surface of the parietal bone formed of reticular collagen fibrils

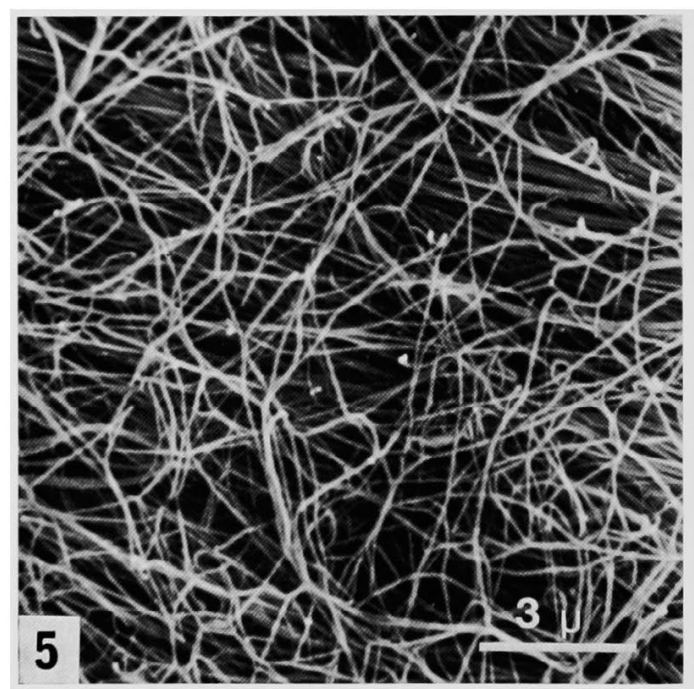

Fig. $\sqrt{3}$ Outermost layer of the external surface of the parietal bone formed of dense networks of collagen fibrils

胎生期には脳の成長に伴って外方へ形成されつう けているので，骨の外面には骨基質が形成され， 逆に内面は吸収が進行しているといわれている。 そこで今回は典型的な膜性骨である胎性期後半の 胎児の頭頂骨を用いて，形成期の膜性骨の超微形 態について検索したので，これまでに報告してき た骨基質の形成面と対比して考察する。

胎生期後半の胎児の頭頂骨の内外面には，きわ

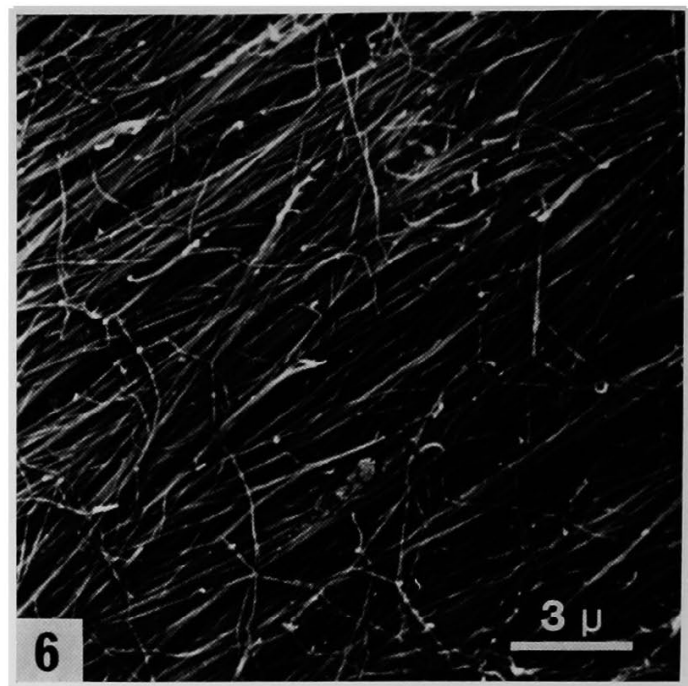

Fig. 6 Outermost layer of the externnal surface of the parietal bone formed of sparse networks of collagen fibrils

めて多数の血管腔が開口している。このことは, 頭頂骨の外面に基質が形成されており, 内面は吸 収されているので，このような時期には骨表面に 多量の血液供給の必要があるために，きわめて多 数の血管が分布していることと考えられる。骨基 質の形成を検索する目的で，著者らがこれまでに 観察した成長期のラットの骨口蓋の上下面にも, 胎児の頭頂骨の内外面と同様にきわめて多数の血 管腔が開口していた ${ }^{12-14)}$ 。成長過程においては, 鼻腔が拡大されるために，口蓋は下降する。そこ で骨口蓋の下面にはきわめて著しく基質が形成さ れ，上面は吸収されているので，成長期の骨口蓋 も，今回試料として用いた形成期の頭頂骨も同様 であるためと考えられる。また, きわめて著しく 骨基質が形成されている時期には，骨表面に開口 している血管孔が著明に増加してくるが，骨基質 形成が緩やかになると，血管孔は小型化するとと もに，数も著しく減少することを確認している ${ }^{15)} 。$

頭頂骨の外表面は一定方向に平行に走向してい る密な膠原原線維で形成されている。膠原原線維 は石灰化骨の表面に，末石灰化層を形成している が，この未石灰化層は徐々に石灰化するものと考 えられる。著者らがこれまでに観察した骨基質形 成面 ${ }^{6,7)}$ に 同様に密な膠原原線維層が形成され ていた。 


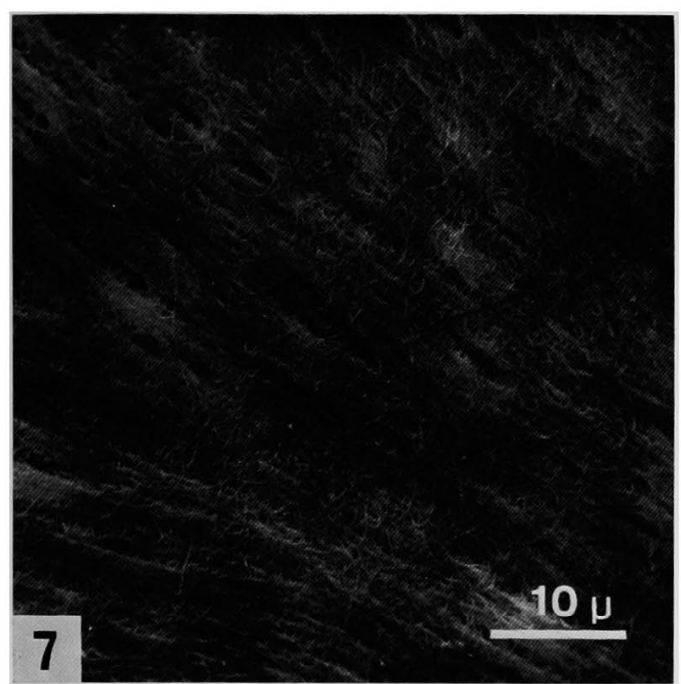

Fig. 7 External surface of the parietal bone formed by compact collagen fibrils running parallel in a uniform direction

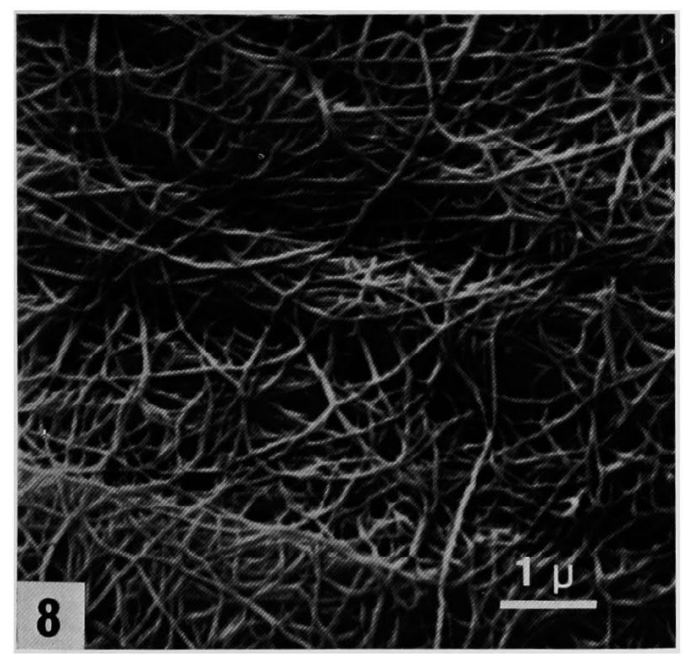

Fig. 8 External surface of the parietal bone showing fusion of the majority of the reticular collagen fibrils of the superficial layer of matrix with the matrix beneath them

頭頂骨の外表面の膠原原線維㬝には，不完全に 形成されている骨小腔が認められる。形成期の骨 基質の最表層には，活発な骨形成能を有している 骨芽細胞が単層に配列されており，骨組織の主成 分である膠原原線維を産生しているが，骨芽細胞 はそれ自体が形成した未石灰化の膠原原線維層に

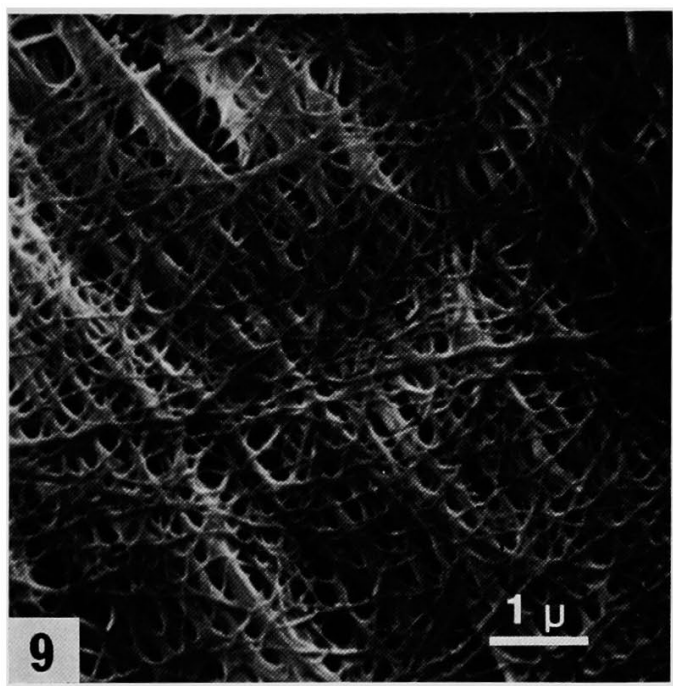

Fig. 9 External surface of the parietal bone showing extremely large amount of canaliculi opened in the matrix surface

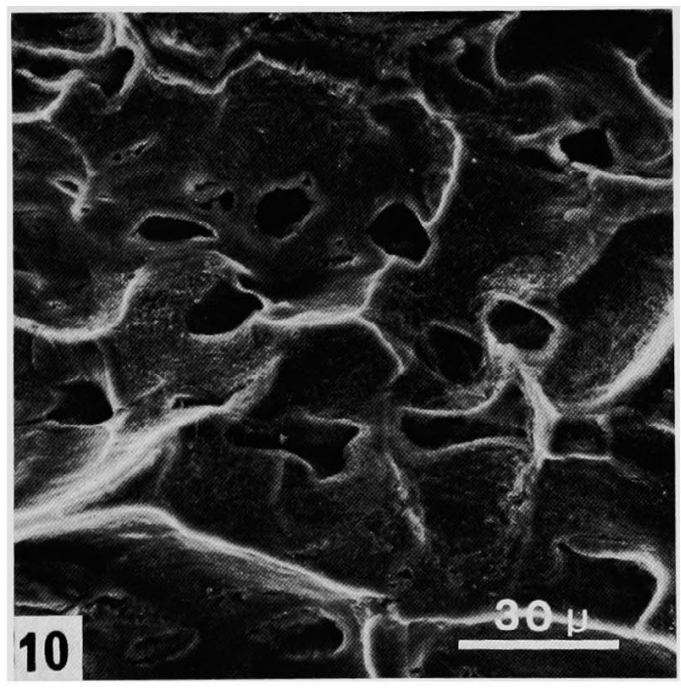

Fig. 10 Internal surface of the parietal bone showing many resorption lacunae irregular in size and shape

徐々に埋人される。そのために，不完全に膠原原 線維層に埋入されている省小腔が認められる。著 者らがこれまでに観察した形成期の骨表面にも， 不完全に形成されたきわめて多数の骨小腔が観察 された ${ }^{6,7,161}$ 。

頭頂骨の外表面の最表層は，不規則な走向の膠 原原線維によって，膠原原線維網が形成されてい 


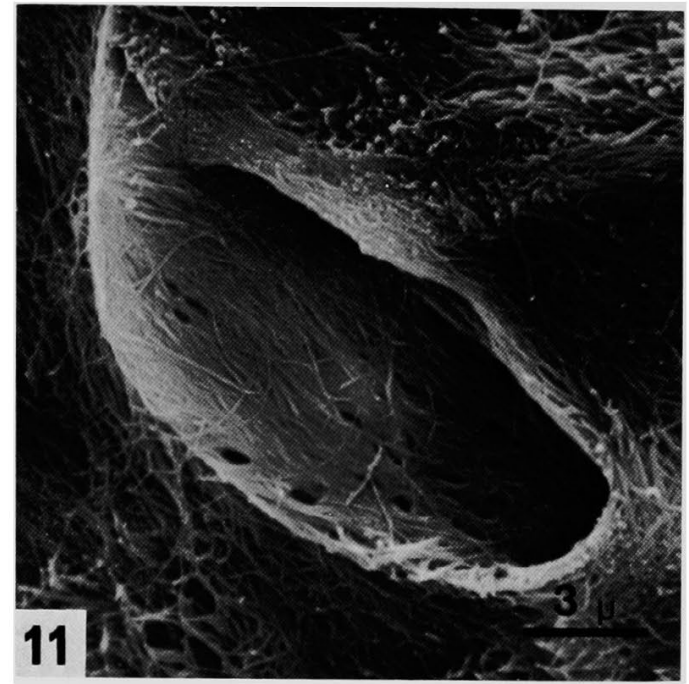

Fig. 11 Osteocyte lacuna exposed at the bottom of the resorption lacuna

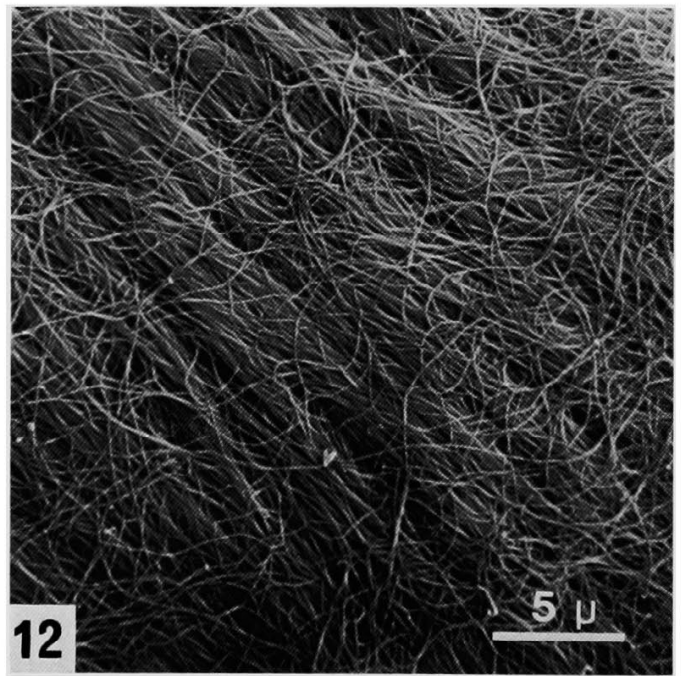

Fig. 12 Superficial layer of the inner wall of blood vessel formed of reticular collagen fibrils

る。著者らがこれまでに観察した骨基質形成面で も，最表層は膠原原線維網によって形成されてい $た^{6,7}$ 。すなわち, 骨基質の最表層に単層に配列さ れている骨芽細胞から分泌された膠原原線維は, 不規則な配列になっているが，その後，膠原原線 維は徐々に規則的に配列されるようになることと 考えられる。基質形成が行われている骨小腔壁も 同様に，密な膠原原線維網で形成されている ${ }^{8-11)}$ 。 頭頂骨の外表面の最表層を形成している膠原原

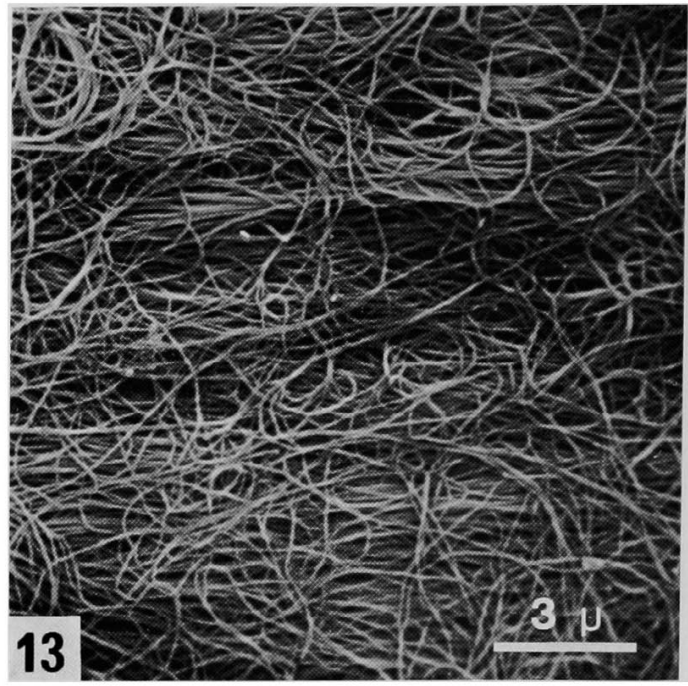

Fig. 13 Superficial layer of the inner wall of blood vessel formed of dense reticular collagen fibrils

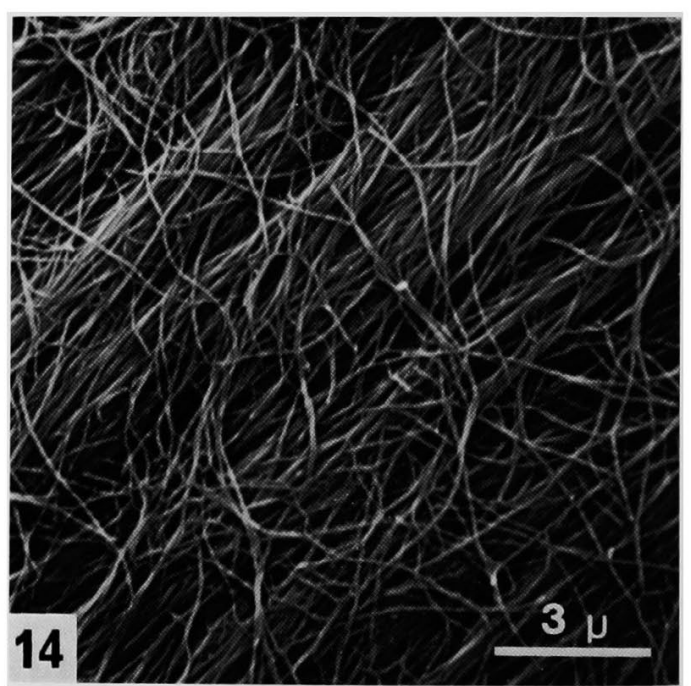

Fig. 14 Superficial layer of the inner wall of blood vessel formed of sparse network of collagen fibrils

線維網には, 密な部分と疎な部分とが認められる。 密な膠原原線維網で形成されている部分は, 疎な 部分よりも著しく基質が新生されている部分と考 えられる。著者らがこれまでに観察した骨基質形 成面の最表層も同様な超微形態を呈していたが, 急速に基質が形成されていると考えられる骨基質 形成面の最表層には，きわめて密な膠原原線維網 によって形成されている半球形または不定形の 5 
$\mu$ 前後の微小構造物が形成されていた。今回観察 した頭頂骨の外表面には，このような微小構造物 は形成されていなかった。このことは，胎児の頭 頂骨は，脳の成長に伴って，基質が徐々に外方 形成されているものと思われる。頭頂骨の外表面 の最表層を構成している密な膠原原線維網が，下 層の膠原原線維層に渝合している部分も認められ た。この部分は休止面であると考えられる。

頭頂骨の内表面は吸収されており，吸収面は大 小様々の多数の不定形の吸收窩からなっている。 各吸収窩は深さが異なっており，吸収窝底には吸 収によって露出された膠原原線維が認められる。 各吸収窩底に認められる膠原原線維の走向は異な っている。このことは，それぞれの吸収窩底の深 さが異なっているので，異なった深さの層板を構 成していた膠原原線維が露出されているためと考 えられる。

胎児の頭蓋冠を構成している頭頂骨は，内部の 脳の成長に伴って，内面の基質は吸収され，外面 には基質が形成されることによって，外方へ成長 するとともに彎曲度が緩やかになる。

\section{結論}

胎生期後半の胎児の膜内骨化による形成途上の
頭頂骨の内外面の超微形態を，走査電子顕微鏡に よって観察した結果，次のような結論を得た。

1. 頭頂骨の内外面には骨梁が 形成されてお り，骨梁間にはきわめて多数の血管腔壁が開口し ている。

2. 頭頂骨の外表面は基質が形成されており， 一定方向に平行に走向している密な膠原原線維で 形成されているが，最表層には不規則な走向の膠 原原線維によって，膠原原線維網が形成されてい る。

3. 頭頂骨の内表面は吸収されており，吸収面 は大小様々の多数の不定形の吸収窩からなってい る。各吸収窩底には走向の異なっている膠原原線 維が露出されている。

4. 吸収窩底には吸収によって露出された骨小 腔が認められる。骨小腔壁はきわめて密な一定方 向に走向している膠原原線維で形成されている が，壁の最表層は網状構造を呈している膠原原線 維で形成されている。

5． 頭頂骨の内外面に開口している血管腔壁に は基質が形成されており，一定方向にほぼ平行に 走向している密な膠原原線維で形成されている が，最表層には不規則な走向の膠原原線維によっ て，膠原原線維網が形成されている。

抄録：膜性骨の形成過程の超微形態を検索する目的で，走查電子顕微鏡によって，胎生期後半の胎児の頭 頂骨の内外表面の超微形態を観察した。頭頂骨の内外面には骨梁が形成されており，骨梁間にはきわめて多 数の血管腔壁が開口している。頭頂骨の外表面は基質が形成されており，ほぼ一定方向に平行に走向してい る密な膠原原線維で形成されているが，最表層には不規則な走向の膠原原線維によって，膠原原線維網が形 成されている。頭頂骨の内表面は吸収されており，吸収面は大小様々の多数の不定形の吸収窝からなってい る。各吸収窩底には走向の異なっている膠原原線維が露出されている。吸収窩底には吸収の進行によって露 出された骨小腔が認められる。頭頂骨の内外面に開口している血管腔壁は基質が形成されており，ほぼ一定 方向に平行に走向している密な膠原原線維で形成されているが，最表層は不規則な走向の膠原原線維によっ て, 膠原原線維網が形成されている。

\section{文献}

1) Fujimoto, M., Egawa, K., Ide, Y. and Takiguchi, R. : Scanning electron microscopy of calcifying cartilage matrix in the mandibular condyle. Bull. Tokyo Dent. Coll., 21 : 41-47, 1980.

2）藤本 誠, 谷内良弘, 滰口励司 : 下買頭軟骨の エネルギー分散 X線分析. 歯基碳誌, 22 : 412$417,1980$.
3）藤本 誠, 後藤 清, 滝口励司：下頻頭軟骨の エネルギー分散 $\mathrm{X}$ 線分析と走查電子顕微鏡的観 察. 解剖誌, $56: 72-78,1981$.

4）藤本 誠：下䫟頭軟骨基質の石灰化についての 走查電子顕微鏡的観察. 歯基碟誌, $24: 62-71$, 1982.

5）江川 董, 新村明達, 滝口励司 : 下顎頭の軟骨 内骨化についての走查電子顕微鏡的研究. 歯基 礴誌，22：661-665, 1980.

6）江川 莗, 小口幸司, 山合友一朗 : 骨基僙形成 
面の走查電子顕微鏡的研究. 昭歯誌, $1: 23-27$, 1981.

7）申 富雄, 杉山 裕, 鈴木いくよ, 滝口励司 : 胎児骨の基質形成についての走查電顕所見. 歯 基礎誌, $22: 470-474,1980$.

8）後藤 清: 骨小腔壁の基質形成に伴う微細構造 上の変化について. 歯科医学, $42: 459-471$, 1979.

9）鈴木いくよ, 後藤 清, 後藤周二, 滝口励司 : 骨小腔壁の走查電子顕微鏡的研究. 歯基礎誌, 21 : 622-628, 1979.

10）鈴木いくよ, 後藤 清, 滝口励司 : 骨小腔壁の 微細構造についての走査電子顕微鏡的研究. 口 科誌, 28 : 394-397, 1979.

11) Egawa, K., Suzuki, I. and Takiguchi, R. :
Fine structure of the osteocyte lacunar wall. Bull. Tokyo Dent. Coll., 21 : 127-136, 1980.

12) Takiguchi, R.: Scanning electron microscopy of the bony palate of the rat. Bull. Tokyo Dent. Coll., $20: 83-92,1979$.

13）滝口励司, 江川 䓂, 申 富雄 : ラットの骨口 蓋の 走查電子顕微鏡的研究. 歯基礎誌, 21 : 285-291, 1979.

14）江川 薑 : 増龄に伴う骨基質形成の変化につい て. 歯基礎誌, $23:$ 147-153, 1981.

15）江川 䕒, 中村輝夫, 谷内良弘: 増龄に伴う狉 骨表面の血管孔の密度の変化について，歯基礎 誌, 22 : 418-421, 1980.

16）谷内良弘：形成期の骨表面の超微形態学的研究. 歯科医学, $44: 125-137,1981$. 